\title{
Estimating grassland production loss due to fire for a semi-arid climate
}

\author{
H.A. Snyman ${ }^{\#}$ \\ Department of Animal, Wildlife and Grassland Science, University of the Free State, P.O. Box 339, \\ Bloemfontein 9300, South Africa
}

\begin{abstract}
Accidental, runaway veld fires cause enormous fodder flow problems in dry regions. It was the objective of this study to estimate the short-term (one year) impact of fire over 10 growing seasons (1995/96 - 2004/05) on the productivity (aboveground phytomass and litter) of a semi-arid grassland ecosystem. Fire caused a $41 \%$ decrease in basal cover over the first season following burning. On average over the study period the seasonal aboveground phytomass and litter production were decreased significantly, from 1536 to $1150 \mathrm{~kg} / \mathrm{ha}$ and $111-42 \mathrm{~kg} / \mathrm{ha}$, respectively by fire. Seasonal production losses due to fire varied between 238 and $444 \mathrm{~kg} / \mathrm{ha}$. The relationship between aboveground phytomass production loss due to fire and two independent variables, namely seasonal rainfall and fuel load (aboveground phytomass plus litter) before burning, was investigated. One year after an accidental fire the production losses can be accurately (79\%) estimated if the fuel load before burning is known. In general, the higher the fuel load before burning, the greater the production loss due to fire. The relationships can also serve as a simple empirical model for managers to determine short-term production loss due to unplanned fires in a semi-arid grassland. This information can serve as a scientific guideline in court cases in estimating production losses in claims for damages caused by fires.
\end{abstract}

\footnotetext{
Keywords: Aboveground phytomass production, basal cover, fuel load, litter

\#E-mail: Snymanha.sci@ufs.ac.za
}

\section{Introduction}

In the semi-arid sweet grassland areas of South Africa, with a mean annual rainfall of $500 \mathrm{~mm}$ or less (about $65 \%$ of the grasslands in South Africa), herbage production is determined not only by water availability, but also by unexpected or unplanned veld fires (Snyman, 2005), which could result in risk management practices in both agricultural and conservation areas (Snyman, 2003a). When the production potential of these grasslands was overestimated after burning, the resulting overgrazing would also cause a decline in veld condition (Snyman, 2003b). These unplanned events normally take place during the dormant winter period (June - August). Accidental, runaway veld fires will not only have a short-term influence on productivity of the grassland ecosystem, but may also have a major residual effect on the next growing season, depending on subsequent climatic conditions and post-fire management (Trollope, 1999).

The National Livestock Strategy puts into perspective the current and future importance of the livestock sector, highlighting its contribution to the national economy, food security and rural development (Meissner, 2006). One of the important aims of this strategy is to ensure that land use practices do not result in over-utilization of the natural resources, but to follow sound management and sustainability plans. If the impact of a fire in these ecologically sensitive arid and semi-arid areas is not calculated in the management for sustainable utilization of the grassland ecosystem after such an unplanned event, it could cause a decline in veld condition and result in degradation of the ecosystem (Everson, 1999). Therefore, it was the objective of this study to estimate the short-term impact of fire, which is a normal phenomenon in the semi-arid areas, on the productivity of the grassland ecosystem.

\section{Material and Methods}

The study was conducted at Bloemfontein $\left(28^{\circ} 50^{\prime} \mathrm{S} ; 26^{\circ} 15^{\prime} \mathrm{E}\right.$, altitude $\left.1350 \mathrm{~m}\right)$, in the semi-arid summer rainfall (annual average $560 \mathrm{~mm}$ ) region of South Africa. At the start of this study the grassland was in good condition (grassland condition score was $92 \%$ of that of the benchmark site) and dominated by the climax species, Themeda triandra, with Eragrostis chloromelas and Elionurus muticus also occurring relatively abundantly. The data were collected from a typical Dry Sandy Highveld grassland. The soil was a 
fine sandy loam soil of the Bloemdal Form (Roodepoort family-3 200; Soil Classification Working Group, 1991). Clay percentage increased down the profile from $10 \%$ in the A-horizon $(0-300 \mathrm{~mm}$ depth), to $24 \%$ in the B1-horizon $(300-600 \mathrm{~mm})$ and $42 \%$ in the B2-horizon $(600-1200 \mathrm{~mm}$ depth).

The research was conducted on six plots of $3 \mathrm{~m} \times 10 \mathrm{~m}$ each, re-applied every year on a new area (on the same soil form), over a 10-year period (1995/96 - 2004/05 season). Each plot was monitored only over a one year period. The treatments randomly applied, consisted of the burning (head fire) of a plot and a control without burning. The experimental layout was a fully randomized design with three replications for each treatment.

The burning (head fire) treatments were applied each year at the end of August by which time the grass fuel was dry. Burning was applied in a morning when a light wind was blowing. To limit the fire to the specific burnt plot, plants surrounding the plot (edge effect of $2 \mathrm{~m}$ ) were cut short and soaked wet before burning. The plots were protected from grazing over the trial period. Before the burning treatment was applied, the grassland was harvested to a height of $30 \mathrm{~mm}$ at the end of each growing season.

The basal cover and botanical composition were determined with a bridge-point apparatus, where 500 points (nearest plant and strikes) were recorded per plot before the fire and at the end of the one growing season following burning (Snyman, 2004). Fuel load included the aboveground phytomass as well as the litter just before burning (August). Firstly, the litter (dead plant parts separate from grass tufts) was handraked in 10 quadrates $\left(1 \mathrm{~m}^{2}\right.$ each) randomly placed in control plots adjacent to the burning plots. After that, in the same plots, the aboveground phytomass production component, comprising the previous season's production, was measured by cutting the grass to soil level. In the laboratory, the litter was washed under running water over a $2 \mathrm{~mm}$ sieve to get rid of attached soil particles. Harvested materials were oven-dried at $90{ }^{\circ} \mathrm{C}$ for 72 hours before being weighed. Care was taken that the annual litter collection and production measurements took place in a new area each time by marking it with steel pens.

Seasonal herbage production or regrowth from burnt grassland and control plots were determined at the end of the growing season (April) in each plot by clipping the plants in 10 quadrates $\left(1 \mathrm{~m}^{2}\right.$ each, randomly placed) to a height of $30 \mathrm{~mm}$. The relation between aboveground phytomass production loss due to fire, and two independent variables, seasonal rainfall and fuel load prior to burning, were examined. Multiple regression analysis was used to analyse the date of the 10 years. The fuel load before burning and the season's rainfall following the burning were regressed on the seasonal production loss due to burning (seasonal unburnt production minus regrowth of burnt grassland). All basal cover and production data were analysed by using a one-way ANOVA (Winer, 1974), according to the procedures of SAS (2001).

\section{Results and Discussion}

The long-term average ( \pm s.e.) aboveground phytomass production of the study area was $1692 \pm 31$ $\mathrm{kg} / \mathrm{ha} / \mathrm{a}$ (ranging between $2678-613 \mathrm{~kg} / \mathrm{ha} / \mathrm{a}$ : Snyman 1998; 1999), compared to the average of $1751 \pm 26$ $\mathrm{kg} / \mathrm{ha} / \mathrm{a}$ (ranging between $2421-815 \mathrm{~kg} / \mathrm{ha} / \mathrm{a}$ ) for the 10 years preceding burning in this study. Therefore, the fuel load approached the long-term loads for the study area.

Fire caused on average $( \pm$ s.e. $)$ a $41 \%$ decrease $(\mathrm{P} \leq 0.01)$ in basal cover (from $7.66 \pm 0.24$ to 4.51 $\pm 0.11 \%$ ) over the first season after burning. Fire caused most damage to basal cover ( $48 \%$ decrease) during the season with the highest rainfall $(2001 / 02=816 \mathrm{~mm})$ and therefore the best aboveground phytomass production $(2614 \mathrm{~kg} / \mathrm{ha})$. The main reason for this drastic decrease in basal cover could be the hotter fire following the build-up of dry matter and therefore the severe die-off of tufts. On the other hand, the decrease in basal cover caused by fire after a very dry growing season $(2003 / 04=412 \mathrm{~mm})$ was only $31 \%$, which is still very high compared to the cover of unburnt grassland. Everson (1999) and Snyman (2003a; b) also reported a decrease in basal cover on grassland due to fire.

Fire did not influence the botanical composition of the canopy drastically. The climax grasses such as Cymbopogon plurinodis, Elionurus muticus and Themeda triandra were influenced most by fire, with a decrease in species composition of 9, 12 and 14\%, respectively. The subclimax Eragrostis chloromelas grass increased by $6 \%$ in species composition after the fire. According to Tainton \& Mentis (1984), various burning regimens do not appear to fundamentally change the composition of a grassland.

During the study period the annual rainfall varied between 412 and $816 \mathrm{~mm}$, with the precipitation of five of the years being above the long-term average of $560 \mathrm{~mm}$ for the study area. The average seasonal production or regrowth of the burnt and unburnt grassland differed $(\mathrm{P} \leq 0.01)$ from each other for all 10 trial seasons. Over the first season following the fire, the burnt grassland produced on average ( \pm s.e.) $1150 \pm 21$ 
$\mathrm{kg} / \mathrm{ha}$, which was $25 \%$ less than that of the unburnt grassland (1 $536 \mathrm{~kg} / \mathrm{ha})$. The average aboveground phytomass production over the study period ranged between 1121 and $2614 \mathrm{~kg} / \mathrm{ha}$ for unburnt grassland and between $814-2110 \mathrm{~kg} / \mathrm{ha}$ for burnt grassland. According to most researchers burning clearly reduces yield in the summer immediately following the fire treatment (Everson, 1999; Morris \& Fynn, 2001). In the Tall Grassveld of KwaZulu-Natal, for example, December yields following spring burning averaged only about $40 \%$ of those recorded after mowing. By February, however, differences between a burnt and mown rangeland had declined to between 10 and $35 \%$, and the next season differences were even less pronounced (Everson, 1999). Production losses due to fire, which is also a function of seasonal rainfall (between 412 and $861 \mathrm{~mm}$ over the trial period) varied between 238 and $444 \mathrm{~kg} / \mathrm{ha}$.

Over all 10 subsequent growing seasons following the fire treatment the litter was on average $61 \%$ less $(\mathrm{P} \leq 0.01)$ (a reduction from 111 to $42 \mathrm{~kg} / \mathrm{ha}$ ) due to the burning compared to the unburnt treatment. Similarly, other researchers found a significant decrease in litter after burning (Blank et al., 1994; Snyman, 2003a). The average litterfall from the unburnt grassland of $111 \mathrm{~kg} / \mathrm{ha}$ recorded in this study was substantially less than the $750 \mathrm{~kg} /$ ha reported for a semi-arid Astrebla pectinata grassland in Australia (Ingram, 2002). As a proportion of annual phytomass production of the unburnt grassland, the average litterfall of $7.7 \%$ in this study was also less than reported for other semi-arid rangelands, viz. 16\% (Astrebla pectinata grassland; Ingram, 2002), 11\% (Themeda triandra grassland; Ingram, 2002), 9\% (Eragrostis xerophila grassland; Ingram, 2002). In most arid and semi-arid grasslands, litter turnover is very slow (Whitford et al., 1988).

The aboveground phytomass production loss due to fire $(\mathrm{kg} / \mathrm{ha})$ was estimated using the non-linear procedure of SAS (2001). All phytomass productions are on a dry mass basis. The regression equation $(\mathrm{P} \leq$ $0.01)$ is described as follows:

$$
\mathrm{y}=-98.18+044 x_{1}+0.04 x_{2}(\mathrm{n}=10 ; \mathrm{r}=0.89)
$$

where: $\mathrm{y}$ is the production loss due to fire $(\mathrm{kg} \mathrm{DM} / \mathrm{ha}), x_{1}$ is the seasonal rainfall $(\mathrm{mm})$ and $x_{2}$ is the fuel load without burning (kg DM/ha).

For one year after an accidental fire, the production losses can be estimated with a $79 \%$ accuracy if the fuel load before burning was determined or known. The equation clearly indicated that the higher the fuel load before burning, the greater the production loss due to fire.

The simple linear regression equation obtained between aboveground phytomass production loss due to fire, with seasonal rainfall is as follows:

$$
\mathrm{y}=0.79 x-241.26(\mathrm{n}=10 ; \mathrm{r}=0.92 ; \mathrm{P} \leq 0.01)
$$

where: $\mathrm{y}$ is the production loss due to fire $(\mathrm{kg} \mathrm{DM} / \mathrm{ha})$ and $\mathrm{x}$ is the seasonal rainfall $(\mathrm{mm})$.

The linear regression equation obtained between aboveground phytomass production loss due to fire with aboveground phytomass production without fire (fuel load) is as follows:

$$
\mathrm{y}=0.09 x+41.32(\mathrm{n}=10 ; \mathrm{r}=0.94 ; \mathrm{P} \leq 0.01)
$$

where: $y$ is the production loss due to fire ( $\mathrm{kg} \mathrm{DM} / \mathrm{ha})$ and $\mathrm{x}$ is the fuel load $(\mathrm{kg} \mathrm{DM} / \mathrm{ha})$.

With information on seasonal rainfall or fuel load before the fire, the production loss due to fire can be estimated with 85 and $88 \%$ accurately, respectively.

\section{Conclusions}

Since rainfall and unplanned veld fires are the most important factors limiting veld production in the drier areas of South Africa, higher animal production can only be realised through better genetic (animal) material combined with an increase in fodder production. Therefore, management of the grassland ecosystem for sustainable animal and plant production requires the application of correct post-fire management practices. A better understanding of the dynamics of the grassland ecosystem under different fire regimens can improve management, which in turn can reduce drought disasters and veld degradation. Scientific knowledge of the impact of veld fires on the functioning of the ecosystem can therefore lead to 
higher vegetation production, which indirectly can contribute to increased animal productivity in the form of red meat and fibre.

The necessary knowledge of the influence of fires on veld productivity is also important for adjusting stocking rates and thereby ensuring the sustainable utilisation of the grassland ecosystem. These significant relationships between effects of fire, rainfall and fuel load on phytomass production, based on 10 years of observations, can serve as a simple empirical model for managers to determine short-term production losses due to fire. This information can also serve as a scientific guideline in estimating production losses in claims for damages suffered in cases of negligent grassland fires.

\section{References}

Blank, R.R., Leah, A. \& Young, J.A., 1994. Soil heating, nitrogen, cheatgrass and seedbed microsites. J. Range Mangnt. 47, 33-37.

Everson, C.S., 1999. Veld burning in different vegetation types. In: Veld Management in South Africa. Ed. Tainton, N.M., University of Natal Press, Pietermaritzburg, South Africa. pp. 228.

Ingram, L.J., 2002. Growth, nutrient cycling and grazing of three perennial tussock grasses in the Pilbara region of NW Australia. PhD thesis, University of Western Australia. 280 pp.

Meissner, H.H., 2006. Challenges for the animal sciences industries and profession- a strategic perspective. Proc. 41 st Congr. S. Afr. Soc. Anim. Sci., Bloemfontein, South Africa. pp. 1-4.

Morris, C. \& Fynn. R., 2001. The Ukulinga long-term grassland trials: Reaping the fruits of meticulous, patient research. Bull. Grassl. Soc. S. Afr. 11, 7-22.

Snyman, H.A., 1998. Dynamics and sustainable utilization of the rangeland ecosystem in arid and semi-arid climates of southern Africa. J. Arid Environ. 39, 645-666.

Snyman, H.A., 1999. Quantification of the soil-water balance under different veld condition classes in a semi-arid climate. Afr. J. Range For. Sci. 6, 108-117.

Snyman, H.A., 2003a. Short-term response in productivity following an unplanned fire in a semi-arid rangeland of South Africa. J. Arid Environ. 56, 465-485.

Snyman, H.A., 2003b. Fire and the dynamics of semi-arid grassland: Influence on plant survival, productivity and water-use efficiency. Afr. J. Range For. Sci. 20, 29-39.

Snyman, H.A., 2004. Short-term influence of fire on seedling establishment in a semi-arid grassland of South Africa. S. Afr. J. Bot. 70, 215-226.

Snyman, H.A., 2005. Influence of fire on root distribution, seasonal root production and root/shoot ratios in grass species in a semi-arid grassland of South Africa. S. Afr. J. Bot. 71, 133-144.

SAS, 2001. Statistical Analysis System user's guide. (Version 8.2) SAS Institute Inc., Carey, North Carolina, USA.

Soil Classification Working Group, 1991. Soil Classification: A Taxonomic System for South Africa, Department of Agriculture Development, Pretoria, South Africa. 226 pp.

Tainton, N.M. \& Mentis, M.T., 1984. Fire in grassland. In: Ecological Effects of Fire in South African Ecosystems. Eds. Booysen, P.deV. \& Tainton, N.M., Ecological Studies, No. 48, Springer, Berlin. $510 \mathrm{pp}$.

Trollope, W.S.W., 1999. Fire behaviour. In: Veld Management in South Africa. Ed. Tainton, N.M., University of Natal Press, Pietermaritzburg, South Africa. pp. 218.

Whitford, W.G., Stinnett, J. \& Anderson. J., 1988. De-composition of roots in a Chihuahuan desert ecosystem. Oecologia 75, 8-11.

Winer, B.J., 1974. Statistical Principles in Experimental Design. McGraw-Hill, London. pp. 218. 